\title{
The impact of negatively reciprocal inclinations on worker behavior: Evidence from a retrenchment of pension rights
}

Citation for published version (APA):

Montizaan, R. M., de Grip, A., Cörvers, F., \& Dohmen, T. J. (2016). The impact of negatively reciprocal inclinations on worker behavior: Evidence from a retrenchment of pension rights. Management Science, 62(3), 668-681. https://doi.org/10.1287/mnsc.2015.2157

Document status and date:

Published: 01/03/2016

DOI:

10.1287/mnsc.2015.2157

Document Version:

Publisher's PDF, also known as Version of record

Document license:

Taverne

Please check the document version of this publication:

- A submitted manuscript is the version of the article upon submission and before peer-review. There can be important differences between the submitted version and the official published version of record.

People interested in the research are advised to contact the author for the final version of the publication, or visit the DOI to the publisher's website.

- The final author version and the galley proof are versions of the publication after peer review.

- The final published version features the final layout of the paper including the volume, issue and page numbers.

Link to publication

\footnotetext{
General rights rights.

- You may freely distribute the URL identifying the publication in the public portal. please follow below link for the End User Agreement:

www.umlib.nl/taverne-license

Take down policy

If you believe that this document breaches copyright please contact us at:

repository@maastrichtuniversity.nl

providing details and we will investigate your claim.
}

Copyright and moral rights for the publications made accessible in the public portal are retained by the authors and/or other copyright owners and it is a condition of accessing publications that users recognise and abide by the legal requirements associated with these

- Users may download and print one copy of any publication from the public portal for the purpose of private study or research.

- You may not further distribute the material or use it for any profit-making activity or commercial gain

If the publication is distributed under the terms of Article 25fa of the Dutch Copyright Act, indicated by the "Taverne" license above, 


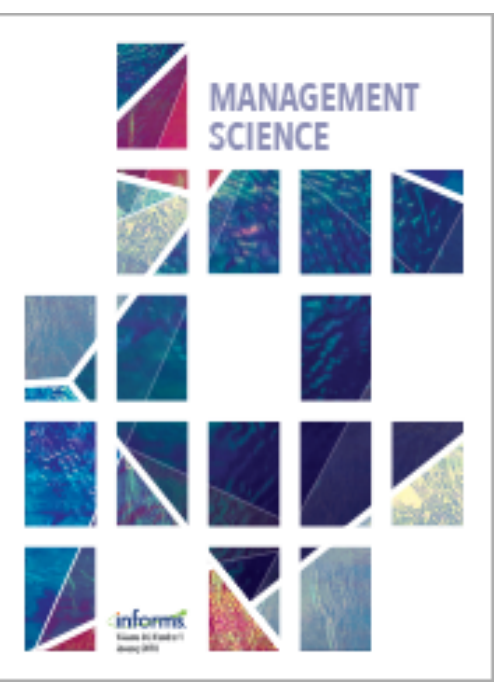

\section{Management Science}

Publication details, including instructions for authors and subscription information: http:// pubsonline.informs.org

\section{The Impact of Negatively Reciprocal Inclinations on Worker Behavior: Evidence from a Retrenchment of Pension Rights}

Raymond Montizaan, Andries de Grip, Frank Cörvers, Thomas Dohmen

\section{To cite this article:}

Raymond Montizaan, Andries de Grip, Frank Cörvers, Thomas Dohmen (2016) The Impact of Negatively Reciprocal Inclinations on Worker Behavior: Evidence from a Retrenchment of Pension Rights. Management Science 62(3):668-681. https:// doi. org/ 10.1287/ mnsc. 2015.2157

\section{Full terms and conditions of use: https://pubsonline.informs.org/page/terms-and-conditions}

This article may be used only for the purposes of research, teaching, and/or private study. Commercial use or systematic downloading (by robots or other automatic processes) is prohibited without explicit Publisher approval, unless otherwise noted. For more information, contact permissions@informs.org.

The Publisher does not warrant or guarantee the article's accuracy, completeness, merchantability, fitness for a particular purpose, or non-infringement. Descriptions of, or references to, products or publications, or inclusion of an advertisement in this article, neither constitutes nor implies a guarantee, endorsement, or support of claims made of that product, publication, or service.

Copyright @ 2016, INFORMS

\section{Please scroll down for article-it is on subsequent pages}

INFORMS is the largest professional society in the world for professionals in the fields of operations research, management science, and analytics.

For more information on INFORMS, its publications, membership, or meetings visit http:// www. informs. org 


\title{
The Impact of Negatively Reciprocal Inclinations on Worker Behavior: Evidence from a Retrenchment of Pension Rights
}

\author{
Raymond Montizaan, Andries de Grip \\ Research Centre for Education and the Labor Market, Maastricht University, 6200 MD Maastricht, Netherlands \\ \{r.montizaan@maastrichtuniversity.nl, a.degrip@maastrichtuniversity.nl\} \\ Frank Cörvers \\ Research Centre for Education and the Labor Market, Maastricht University, 6200 MD Maastricht, Netherlands; and \\ Research Institute for Flexicurity, Labour Market Dynamics and Social Cohesion, Tilburg University, \\ 5037 AB Tilburg, Netherlands, \\ frank.corvers@maastrichtuniversity.nl
}

Thomas Dohmen

Institute for Applied Microeconomics, Department of Economics, Bonn University, 53113 Bonn, Germany; and Research Centre for Education and the Labor Market, Maastricht University, 6200 MD Maastricht, Netherlands, t.dohmen@uni-bonn.de

\begin{abstract}
$\mathrm{W}$ e document that the strength of negatively reciprocal inclinations affects workers' reaction to unfair treatment. We exploit unique matched survey and administrative data on male public sector employees in the Netherlands and compare the job motivation of employees born in 1950, who faced a substantial retrenchment of their pension rights resulting from a pension reform in 2006, to that of slightly older employees who remained entitled to more generous pension benefits. Job motivation is significantly lower among negatively reciprocal employees who were affected by the reform. The adverse effect on job motivation is stronger for negative reciprocal employees born very shortly after the cutoff date of January 1, 1950, as well as for those with many unaffected colleagues, who perceive the policy change as being more unfair. The treatment effect is stronger among workers who are more likely to hold their employer accountable for the drop in their pension rights.
\end{abstract}

Data, as supplemental material, are available at http://dx.doi.org/10.1287/mnsc.2015.2157.

Keywords: reciprocity; job motivation; retrenchment of pension rights

History: Received November 15, 2013; accepted November 30, 2014, by Uri Gneezy, behavioral economics.

Published online in Articles in Advance August 17, 2015.

\section{Introduction}

Economists and psychologists have provided ample evidence from controlled laboratory studies that reciprocity is a key driver of human motivation (Bowles 2008). ${ }^{1}$ Several field experiments (e.g., Falk 2007, Falk and Zehnder 2013) show that reciprocal motives have a significant impact on human behavior outside stylized laboratory environments. Theory predicts that reciprocity also affects labor market outcomes (e.g., Akerlof 1982, Rabin 1993). Important implications are, for example, that positively reciprocal employees increase their efforts above the minimum required level when treated generously by their employers and that negatively reciprocal workers retaliate against

\footnotetext{
${ }^{1}$ Numerous studies show that individuals reciprocate trust in investment games (Berg et al. 1995). Moreover, it is well documented that individuals are willing to reject unfair offers in ultimatum games, even at personal costs (e.g., Güth et al. 1982, Camerer and Thaler 1995), and that participants in public good games are prepared to punish free riders (e.g., Fehr and Gächter 2000).
}

their employers for unfair treatment, for example, by reducing effort.

Previous empirical work on the role of reciprocity in employment relationships focused largely on the impact of positive reciprocity on workers' effort response in gift exchanges. Convincing evidence of in-kind responses by workers (i.e., higher effort provision) to the friendly actions of employers (i.e., a higher wage payment) has been found in stylized labor markets in laboratory experiments (e.g., Fehr et al. 1993, 1998; Brown et al. 2004). Evidence from field experiments on the effect of positive reciprocity in employment relationships is somewhat less conclusive. ${ }^{2}$ Field evidence on the impact of unfair treatment on worker motivation and effort provision is

\footnotetext{
${ }^{2}$ Despite the overwhelming evidence of reference-dependent fairness concerns (e.g., Fehr et al. 1993, 2009), researchers still debate on the extent to which employers' generous treatment of workers causes increased effort provision. Gneezy and List (2006) find that an unexpected salary raise has only a short-lived positive effect
} 
more consistent. A fascinating case study by Krueger and Mas (2004) documents that a labor strife at a U.S. tire production site coincided with the production of substantially lower-quality tires. This arguably resulted from reduced effort and care of workers during the strife, suggesting that harmful reciprocations are important in actual labor market settings. Corroborating findings are documented by Mas (2006, 2008), Kube et al. (2013), and Cohn et al. (2014). ${ }^{3}$ Related studies in psychology have also documented that workers react to wage cuts by harming their employer (see, e.g., Greenberg 1990). None of these studies, however, ascertains whether the degree of an individual's negative reciprocity affects the strength of his negative reaction when being treated unfairly.

Our study fills this gap. Since we have a direct measure of employees' negatively reciprocal inclinations, we can push the analysis of the drivers of reciprocal behavior one step further and establish that negative reciprocal inclinations drive negative reciprocal behavior. Using a regression discontinuity design (Imbens and Lemieux 2008, Lee and Lemieux 2010), we analyze the impact of a retrenchment of pension rights on job motivation and show that the strength of an employee's reaction to this unfair treatment depends on the strength of his negative reciprocal inclinations. ${ }^{4}$ The pension rights of Dutch public sector employees born after December 31, 1949, were curtailed by a law change that abolished the tax deductibility of contributions to sectoral early

on work effort in a gift exchange game. Cohn et al. (2015) show that an unexpected wage increase raises effort of workers who felt underpaid at the baseline wage, but has no effect on effort provision of workers who felt paid fairly at the baseline wage. Bellemare and Shearer (2009) documented that providing a bonus unrelated to past productivity in a field experiment at a tree-planting firm has a significant and positive effect on productivity. Kube et al. (2012) demonstrate that nonmonetary gifts have a much stronger impact on worker effort provision than monetary gifts. Complementary correlational evidence for actual labor markets has been provided by Dohmen et al. (2009). They analyzed survey data and showed that measures of positively reciprocal dispositions of respondents in the German Socio-Economic Panel (SOEP) study are significantly correlated with higher wages and greater work effort.

${ }^{3}$ Mas (2006) documented a deterioration of police performance in the aftermath of adverse outcomes in final offer arbitrations for police unions in New Jersey. Mas (2008) demonstrated that quarrels between a union and Caterpillar coincided with substantially reduced quality of construction equipment produced by Caterpillar during that period. Kube et al. (2013) showed that wage cuts have a detrimental and persistent impact on the productivity of student workers in a data entry job, whereas an equivalent wage increase has no effect. In another field experiment, Cohn et al. (2014) found that performance on the work task (selling promotion cards) deteriorated when wages were cut. They also demonstrated that the drop in performance was more marked when the coworker's wage was not cut

${ }^{4}$ Regression discontinuity designs have recently also been applied by Berger and Pope (2011) and Tucker and Zhang (2011). retirement schemes. Workers born before 1950 were exempted from this change. In the public sector, the national government is both the initiator of the pension reform and the employer. For the public sector we can therefore exploit the specific situation that, since the government initiated the policy change, public sector employees born in 1950 are likely to perceive their employer as directly responsible. The retrenchment of pension rights of the younger cohorts constitutes a breach of an informal agreement because the prospect of early retirement with high pension benefits has been emphasized as an attractive job characteristic in the recruitment of public sector workers since the second half of the 1970s.

We conjecture that workers born in 1950 who compare their pension rights to their own status quo before the policy change and to those who were born in 1949 and still enjoy the older, more generous pension plan are likely to perceive the policy change as unfair. We therefore expect that the treated employees (i.e., those born in 1950) are, on average, less motivated in their job than workers in our control group, who are slightly older (i.e., born in 1949) but otherwise similar. Moreover, if negative reciprocal inclinations drive negative reciprocal behavior, we should expect that among the treated workers, those with strongly negatively reciprocal inclinations show a stronger reaction to the retrenchment of their pension rights than their treated colleagues who have only weak negatively reciprocal inclinations. Using unique matched survey and administrative pension fund data on male employees in the Dutch public sector who were born in either 1949 or 1950, we test these hypotheses by comparing job motivation, a key determinant of work effort, for employees affected by the retrenchment of pension rights (treatment group) with job motivation of unaffected employees born in 1949 (control group) and show that the strength of the treatment effect depends on the strength of employees' negative reciprocal inclinations.

We measure job motivation by a self-reported survey question. ${ }^{5}$ The predictive power of self-reported job motivation for actual effort provision and performance has been investigated in detail in both the industrial-organizational psychology literature and the literature on organizational and vocational behavior. Various meta-analyses (e.g., Bateman and Organ 1983, Scott and Taylor 1985, Judge et al. 2001, Riketta 2002, Harter et al. 2002, Cooper-Hakim and Viswesvaran 2005, Harrison et al. 2006) have demonstrated that positive self-reported job attitudes

\footnotetext{
${ }^{5}$ Our data do not contain objective performance measures. In fact, it is also difficult to define an objective performance measure that applies to all different jobs in the public sector. Tasks typically differ immensely across sectors and are often complex.
} 
of individual employees, such as job motivation, are positively correlated to performance measures on an individual or business-unit level. ${ }^{6}$ Another strand of literature has examined the relationship between motivation and labor-market success and found that motivational variables are strongly correlated with the future earnings and human capital investments of employees (e.g., Dunifon and Duncan 1997, Bowles et al. 2001). ${ }^{7}$

To measure reciprocal inclinations, we make use of six survey questions by Perugini et al. (2003). In a controlled laboratory study, they performed comprehensive validation tests for their reciprocity scale and showed that the measure for negative reciprocity predicts behavior in ultimatum games.

Our result that workers' reaction to unfair treatment indeed depends on their disposition toward negative reciprocity indicates that the aggregate harmful effects of unfair treatment, which previous studies have documented (e.g., Krueger and Mas 2004), are caused by the reaction of workers with negatively reciprocal inclinations. ${ }^{8}$ Additional evidence strongly supports the idea that the strength of negatively reciprocal motives and the perception of the degree of unfairness mediate the causal effect of unfair treatment on job motivation. For example, negatively reciprocal treated workers who were born closer to the cutoff date (e.g., born in the first quarter of 1950), and those employed in an organization with relatively many untreated colleagues are

\footnotetext{
${ }^{6}$ Several of these analyses distinguished between different types of performance measures and found that job motivation increases performance, irrespective of whether it was measured by supervisory ratings, peer-subordinate ratings, or objective records, such as lateness, absenteeism, punctuality, customer satisfaction, employee turnover, or profit (e.g., Judge et al. 2001, Harter et al. 2002, Harrison et al. 2006). Riketta (2008) performed a meta-analysis that covers studies that exclusively used panel data and showed that self-reported job attitudes are more likely to influence performance than vice versa.

${ }^{7}$ In the past two decades, researchers in strategic human resource (HR) management have developed the ability-motivationopportunity model, which predicts that employee performance is a function of three essential components: ability, motivation, and the opportunity to perform. Several empirical studies have adopted and validated this conceptual framework by showing that motivation-enhancing HR practices indeed increase individual performance (e.g., Huselid 1995, Ichniowski et al. 1997, Batt 2002, Liao et al. 2009, Gardner et al. 2011, Kehoe and Wright 2013). Moreover, it has been found that self-reported job motivation is indeed a crucial mediator between these motivation-enhancing HR practices and the financial performance of organizations (Patterson et al. 2004, Jiang and Lepak 2012).

${ }^{8}$ Our contribution goes beyond that of previous studies that have used the same data set to analyze the effects of the pension reform on training participation (Montizaan et al. 2009), mental health (de Grip et al. 2012), and work attitudes (Montizaan and Vendrik 2014). None of these studies considered heterogeneous effects that depend on negatively reciprocal inclinations.
}

the least motivated after the reform, indicating that they perceive the policy change as particularly unfair. Moreover, among the treated, job motivation is lower among negatively reciprocal public sector employees who work for the central government, most likely because they hold their employer, the government that implemented the policy change, directly accountable for the retrenchment of their pension rights.

The remainder of this paper is organized as follows. The next section provides more details on the exogenous shock in the Dutch public sectors' pension system that generates exogenous variation in the way workers are treated. Section 3 describes the data and presents a detailed analyses showing that the data collection process did not generate potential selection problems that may have hampered the validity of our regression discontinuity design. Section 4 presents the results, and $\S 5$ ends with some concluding remarks.

\section{Reform of the Public Sector's Pension System}

In 2006, a reform in the Dutch pension system abolished the favorable tax deductibility of contributions to early retirement schemes that are part of the second pillar of the Dutch pension system for all employees born in 1950 or later (for details, see Web Appendix B, available as supplemental material at http://dx.doi.org/10.1287/mnsc.2015.2157). ${ }^{9}$ Employees born before 1950 who had been continuously employed in the public sector since April 1, 1997, remained entitled to the generous old pension rights. ${ }^{10}$ The government's intention was to provide stronger incentives for younger cohorts to retire at an older age. Those born in 1950 and thereafter suffered from a dramatic loss of early retirement options. After the reform, a typical employee born in 1950 or later with 40 years of tenure attains a replacement rate of only $64 \%$ when retiring early at the age of 62 years and three months, which is substantially lower than the replacement rate of $70 \%$ that applied to them before the reform and that still applies to workers born before $1950 .{ }^{11}$ The strong differential treatment

\footnotetext{
${ }^{9}$ The Dutch pension system consists of three pillars: (1) a public old age pension that is paid to all inhabitants aged 65 and older, (2) a supplementary sectoral (or firm) pension, and (3) voluntary private pension plans.

${ }^{10}$ The abolition of this favorable tax treatment was not limited to the public sector and also applied to workers in the private sector; however, the major difference between the sectors is that in the public sector the national government is both the initiator of the pension reform and the employer in the sectoral bargaining process. This implies that public sector employees may hold their own employer accountable for the drop in their pension rights.

${ }^{11}$ To attain a replacement rate of $70 \%$, workers who are affected by the reform have to postpone retirement by one year and three months.
} 
of workers born around January 1, 1950, came as a surprise to public sector employees, when the reform was announced on July 18, 2005.

The pension fund Algemeen Burgelijk Pensioenfonds (ABP), which covers all public sector workers, launched a campaign in the second half of 2005 to inform its members about the introduction of the new pension system and to explain its financial implications. A special newsletter was devoted to the new pension system in which unions, employer organizations, and the ABP jointly explained the new flexible pension scheme. All 1.2 million ABP participants received a letter about the core characteristics of the new scheme, and a complete digital service package for public service employers was developed. Therefore, one can assume that on January 1, 2006, most public sector employees born after 1949 and their employers were indeed familiar with the exogenous shock in their pension rights.

Since details of the new pension system were only communicated in the second half of 2005, there was not much scope for workers born on January 1, 1950, or later to fully offset the drop in their pension benefits-that is, by engaging in extra savings plansbecause of the limited time horizon to retirement.

\section{Data}

\subsection{Data Collection}

We use survey data that we match to administrative data for male employees in the public sector who were born in 1949 or $1950 .^{12}$ The administrative data are from the ABP. The data contain detailed information on individuals' pension rights at the ABP, annual wage income, and tenure in the public sector.

The survey data were gathered after the introduction of the new pension system. In January 2007, all 27,871 male public sector employees born in either 1949 or 1950 were invited to participate in our Internet survey by requesting their e-mail addresses. The invitation letter, sent by surface mail, conveyed general information about the social usefulness of the study but did not reveal any information about the (motivation for the) research question or the nature of our research strategy (e.g., we did not inform potential participants that the invitation was sent only to public sector employees born in 1949 and 1950). The letter also explicitly assured confidentiality, so that respondents need not fear repercussions from responding in a socially undesired manner. In March 2007, we invited the 11,458 male public sector

\footnotetext{
${ }^{12}$ The survey and administrative data are only available for these two specific birth cohorts. We focus on male employees because in the Netherlands only a small, highly selective group of women in the 1949 birth cohort does not have career breaks and is eligible for exemption from the reform.
}

employees who had provided their contact details to fill in the Web-based survey. In total, 7,739 individuals completed the questionnaire in 2007. References to the nature of our research question and research strategy were also avoided in the survey itself. In March 2008, we sent an e-mail invitation with a link to a second Web-based survey to all individuals who had logged on to the 2007 questionnaire. This time 6,078 respondents completed the survey. In this second wave, we asked detailed questions on reciprocal motivation, job motivation, and retirement expectations.

In our analyses, we exclude workers employed in certain burdensome occupations (e.g., firemen and ambulance and police personnel), in which other retirement schemes are in place that allow early retirement without a substantial drop in income. In our main analysis, we also restrict the sample to those employees who continuously worked in the public sector since 1997 (thereby excluding 260 employees who are not eligible for the prereform early retirement option even if they were born before 1950). ${ }^{13}$ Because of item nonresponse for the variables of interest, the estimation sample is further reduced to 5,287 men, 2,775 of whom were born in 1950 and constitute the treatment group, whereas the other 2,512 men, born in 1949, belong to the control group.

The dependent variable in our econometric analysis is a self-assessed measure of job motivation. Respondents were asked to indicate how well the following statement applies to them personally: "At times, I have difficulties motivating myself in my job." Answer categories ranged from 1 ("applies perfectly to $\mathrm{me}^{\prime \prime}$ ) to 5 ("does not apply to me at all").

Our measure of reciprocity, one of the key explanatory variables in our analysis, is based on the reciprocity scale developed and validated by Perugini et al. (2003). These authors performed comprehensive validation tests and assessed the predictive power of their reciprocity scale for the behavior of participants in ultimatum games in laboratory experiments conducted in the United Kingdom and Italy. We include the six items that have the highest loadings on the principal components for positive and negative reciprocity and that were also included in the 2005 SOEP wave (see Dohmen et al. 2009) for the behavioral validity of these questions). Respondents had to indicate on a five-point Likert scale ( 1 means "does not apply to me at all" and 5 means "applies perfectly to me") how well they identified themselves with each of the following six statements: (1) "If someone does me a favor, I am prepared to return it"; (2) "If I suffer a serious wrong, I will take revenge as soon as possible, no matter what the costs"; (3) "If somebody puts me in a difficult

\footnotetext{
${ }^{13}$ In a robustness analysis we include the workers who did not work continuously in the public sector since 1997.
} 
Table 1

Descriptive Statistics

\begin{tabular}{|c|c|c|c|c|}
\hline & Entire sample & Born in 1949 & Born in 1950 & $p$-value \\
\hline Take revenge for a serious wrong & $\begin{array}{c}3.06 \\
(1.04)\end{array}$ & $\begin{array}{c}3.06 \\
(1.04)\end{array}$ & $\begin{array}{c}3.06 \\
(1.05)\end{array}$ & 0.78 \\
\hline Retaliate for being put in a difficult position & $\begin{array}{c}2.54 \\
(0.85)\end{array}$ & $\begin{array}{c}2.54 \\
(0.84)\end{array}$ & $\begin{array}{c}2.54 \\
(0.86)\end{array}$ & 0.89 \\
\hline Reciprocate insult with an insult & $\begin{array}{c}2.60 \\
(0.91)\end{array}$ & $\begin{array}{c}2.60 \\
(0.90)\end{array}$ & $\begin{array}{c}2.62 \\
(0.91)\end{array}$ & 0.85 \\
\hline Reciprocate a favor & $\begin{array}{c}4.29 \\
(0.64)\end{array}$ & $\begin{array}{c}4.31 \\
(0.63)\end{array}$ & $\begin{array}{c}4.27 \\
(0.64)\end{array}$ & 0.08 \\
\hline Exert effort to help somebody who is kind & $\begin{array}{c}4.11 \\
(0.62)\end{array}$ & $\begin{array}{c}4.11 \\
(0.62)\end{array}$ & $\begin{array}{c}4.11 \\
(0.62)\end{array}$ & 0.80 \\
\hline Undergo personal costs to help someone who was helpful before & $\begin{array}{c}3.73 \\
(0.70)\end{array}$ & $\begin{array}{c}3.73 \\
(0.69)\end{array}$ & $\begin{array}{c}3.72 \\
(0.71)\end{array}$ & 0.15 \\
\hline Negative reciprocity (averaged) & $\begin{array}{c}2.73 \\
(0.79)\end{array}$ & $\begin{array}{c}2.74 \\
(0.78)\end{array}$ & $\begin{array}{c}2.73 \\
(0.79)\end{array}$ & 0.96 \\
\hline Positive reciprocity (averaged) & $\begin{array}{c}4.04 \\
(0.51)\end{array}$ & $\begin{array}{c}4.05 \\
(0.50)\end{array}$ & $\begin{array}{c}4.04 \\
(0.51)\end{array}$ & 0.13 \\
\hline Expected retirement benefit at age of 62 (in \% of net present wage) & $\begin{array}{c}69.02 \\
(11.67)\end{array}$ & $\begin{array}{c}71.66 \\
(11.67)\end{array}$ & $\begin{array}{c}66.62 \\
(11.14)\end{array}$ & 0.00 \\
\hline Extra pension savings in previous year (1 if savings increased) & $\begin{array}{c}0.25 \\
(0.43)\end{array}$ & $\begin{array}{c}0.22 \\
(0.41)\end{array}$ & $\begin{array}{c}0.27 \\
(0.44)\end{array}$ & 0.00 \\
\hline Yearly wage (in euros) & $\begin{array}{c}53,132 \\
(16,420)\end{array}$ & $\begin{array}{c}53,132 \\
(15,957)\end{array}$ & $\begin{array}{c}53,131 \\
(16,938)\end{array}$ & 0.30 \\
\hline Log size of organization & $\begin{array}{c}7.13 \\
(1.78)\end{array}$ & $\begin{array}{c}7.13 \\
(1.79)\end{array}$ & $\begin{array}{c}7.13 \\
(1.77)\end{array}$ & 0.59 \\
\hline Marital status (1 if married) & $\begin{array}{c}0.92 \\
(0.28)\end{array}$ & $\begin{array}{c}0.92 \\
(0.27)\end{array}$ & $\begin{array}{c}0.91 \\
(0.29)\end{array}$ & 0.08 \\
\hline Bad health (self-reported on five-point Likert scale) & $\begin{array}{c}2.06 \\
(0.72)\end{array}$ & $\begin{array}{c}2.07 \\
(0.72)\end{array}$ & $\begin{array}{c}2.05 \\
(0.72)\end{array}$ & 0.45 \\
\hline Number of observations & 4,520 & 2,147 & 2,373 & \\
\hline
\end{tabular}

Notes. Sample standard deviations are in parentheses below sample averages. The measure of negative reciprocity is the individual's agreement to the three statements on the willingness to take revenge for a serious wrong, to retaliate for being put in a difficult position, and to respond to an insult with an insult. The measure of positive reciprocity reflects the agreement to statements on the willingness to return a favor, to exert effort to somebody who was kind, and to undergo personal costs to help someone who was helpful before. Both measures are based on the average of the three underlying items. Answers for the six reciprocity questions are on a five-point Likert scale between 1 and 5 , with 1 meaning "does not apply to me at all" and 5 meaning "applies perfectly to me." The expected retirement benefit at age of 62 is based on the following survey question: "Suppose you would retire at the age of 62 . How large would your pension benefit be as a percentage of your net wage income"? The yearly wage income is based on administrative data of the public sector's pension fund.

position, I will do the same to him/her"; (4) "I go out of my way to help somebody who has been kind to me before"; (5) "If somebody offends me, I will offend him/her back"; (6) "I am ready to undergo personal costs to help somebody who helped me before." Statements (2), (3), and (5) refer to negative reciprocity; statements (1), (4), and (6) concern positive reciprocity. We construct our measures of positive and negative reciprocity by taking the arithmetic average of a respondent's answers to questions (2), (3), and (5) and (1), (4), and (6), respectively. ${ }^{14}$

A relevant concern is how well these survey questions measure the behavioral reciprocal inclinations of the individuals in our sample. Various factors

\footnotetext{
${ }^{14}$ The questions on job motivation and reciprocity were not placed directly after the questions on retirement expectations. The question on job motivation was placed after a block of questions on training participation. The reciprocity questions were placed after a block of health questions.
}

such as strategic motives, self-serving biases, and lack of attention can induce respondents to distort or unintentionally misreport their true reciprocal behavior (Camerer and Hogarth 1999). However, for the following reasons we are confident that our measures are valid indicators of reciprocity, albeit measured with error. First, our reciprocity measures are experimentally validated. Second, Dohmen et al. (2009) showed that the survey measures of reciprocity employed in this study are correlated with behavioral outcomes in a way that is consistent with theoretical predictions. Third, previous research demonstrated the validity of survey questions about preferences, attitudes, and behavior (e.g., Fehr et al. 2002, Bellemare and Kröger 2007, Dohmen et al. 2011, Falk and Zehnder 2013).

\subsection{Descriptives}

Table 1 presents descriptive statistics for the estimation sample (entire sample), and separately for the 
control group (born in 1949) and treatment group (born in 1950). The last column shows the $p$-values for the tests of the hypothesis that the treatment and control group are the same. We do not observe significant differences in the average responses to each of the six different reciprocity measures between the treatment and control groups, indicating that the change in pension rights did not affect self-assessed reciprocal inclinations. The sample averages for the three items that measure negative reciprocity range from 2.6 to 3.1 and are smaller than the averages for the items measuring positive reciprocity (4.3 to 3.7). A substantial number of respondents report that the statements on positive reciprocity apply to them perfectly, whereas respondents identify, on average, less with the statements on negative reciprocity. The variance within the negative reciprocity measures is larger than within the positive reciprocity measures. ${ }^{15}$

Table 1 also reports summary statistics for our two reciprocity measures, which are constructed by averaging agreement with the three statements concerning positive and negative reciprocity, respectively. Again, there are no differences in reciprocal behavior between the treatment and control groups according to these measures. There are also no significant between-group differences in the other attributes used in our analyses below, such as annual wage income, the number of years during which workers have built up their pension, marital status, self-reported health status, educational attainment, and the employment subsector.

Figure 1 plots birth quarter averages of job motivation and local polynomial estimates of job motivation on birth date for the treatment and control groups together, with $95 \%$ confidence intervals, and reveals that there is a drop in job motivation around the birth date that divides public sector employees into treatment and control groups. This drop in job motivation for workers who were born just after 1949 suggests a causal impact of the retrenchment of pension rights on the level of job motivation. These regression lines indicate that the discontinuity around the birth date January 1, 1950, is significant.

Ascribing the reduction in job motivation to the retrenchment of pension rights requires that the employees in our sample be aware of the drop in pension rights brought about by the change in law. To verify this, we compare expectations of the level of pension benefits across the treatment and control groups with the following question: "Suppose you would retire at the age of 62 . How large would your pension benefit be as a percentage of your net wage

\footnotetext{
${ }^{15}$ Reassuringly, the distributions of the answers to the six reciprocity questions exhibit very similar patterns as those of respondents' answers in the SOEP (cf. Dohmen et al. 2009).
}

Figure 1 (Color online) Job Motivation

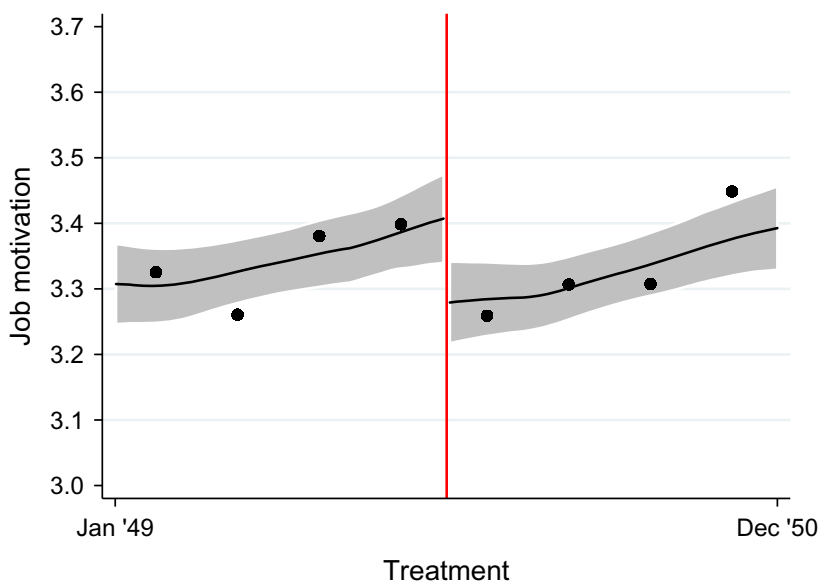

Notes. This figure presents birth quarter averages of job motivation and a local polynomial smooth of job motivation on birth date with a $95 \%$ confidence interval, using a Epanechnikov kernel function. The bandwidth used for the kernel function corresponds to the optimal bandwidth derived from the Imbens and Kalyanaraman (2012) procedure. Job motivation is based on the following five-level Likert item: "At times, I have difficulties motivating myself in my job." Answers categories ranged form 1 ("does applies perfectly to me") to 5 ("does not apply to me at all"). Our sample consists of two birth years where workers born in 1949 are entitled to the old pension rules and workers born in 1950 are subject to the new pension rules. The vertical line in the figure marks the threshold that divides the control from the treatment group.

income"? The average responses shown in Table 1 make it clear that respondents who are affected by the pension reform indeed expect a significantly lower replacement rate. The mean difference in expected retirement benefits between the treatment and control groups amounts to five percentage points, which is remarkably close to the actual mean difference between those groups (6\%). Therefore, we can reasonably conclude that employees are aware of the consequences of the new pension system.

\subsection{Self-Selection}

A relevant issue is whether our outcomes are affected by self-selection. Nonrespondents might have different characteristics than those who filled in the questionnaire, and therefore our results may not be perfectly generalizable to the entire male population of public sector workers born in 1949 or 1950. In this respect, the natural experimental approach used here does not differ from the approaches of other studies that use nonexperimental survey data. However, it is a much greater problem when nonresponse differs between the treatment and control groups, for example, when, among the treated, those who have the strongest feelings about the reform, arguably the most negatively reciprocal, do respond more often. In that situation, the similarity of the two groups is no longer guaranteed, and the regression discontinuity design loses its internal validity. We therefore 
examined in detail the similarity of the treated and untreated respondents.

We are confident that the nonresponse does not differ between the treatment and control groups for several reasons. First, as mentioned before, the potential participants were not informed about the nature of our question and research strategy, and the invitation letter, as well as the survey itself, did not include references to the pension reform. Second, we checked whether there were deviations in the survey participation rate between the treatment and control groups. For each year, the difference in participation rates is extremely small. ${ }^{16}$ In 2007, 30.5\% of all the workers in the treatment group participated in the survey, versus $31.0 \%$ among the control group. In 2008, the survey response rates were $21.6 \%$ for the treatment group and $22.2 \%$ for the control group. Simple $t$-tests show that these small differences in the participation rates are statistically insignificant, with $t$-statistics of 0.97 in 2007 and 1.20 in 2008. Simple probit analyses also confirm that selection into the survey in both survey waves was not related to the treatment. These probit analyses include several control variables available from the administrative data, such as work sector, contractual work hours, birth month, and yearly wage (in logs). ${ }^{17}$ Third, we found no evidence in Table 1 that the treated and untreated respondents differ in their observable characteristics. Both job and personal characteristics are similar across the two groups and not significantly different from each other. ${ }^{18}$

Table 1 shows that there are no significant differences in the average responses of both groups to each of the six different reciprocity measures and the averages of the three statements concerning positive and negative reciprocity. Furthermore, Figures A2-A5 in Web Appendix A show that the distributions of the averages of our positive and negative reciprocity indicators are strikingly similar for the treatment and control groups. This indicates that negatively treated workers, who arguably feel the strongest about the reform, did not more often respond to the questionnaire and that our regression discontinuity approach is internally valid.

\footnotetext{
${ }^{16}$ See also Table A1 in Web Appendix A for a detailed overview of the participation rates.

${ }^{17}$ Figure A1 in Web Appendix A also shows that there is no discontinuity in the participation rate among the treatment threshold, and that there are no significant discontinuities in the participation rate between birth months.

${ }^{18}$ Figure A8 in Web Appendix A presents birth quarter averages of all control variables and a local polynomial smooth of these variables on birth date with a $95 \%$ confidence interval, and shows that all control variables are continuous at the treatment threshold.
}

\section{Estimation Results}

\subsection{Job Motivation, Treatment, and Negative Reciprocity}

We start our analysis by documenting a strong and significant impact of unfair treatment on job motivation in Table 2. Column (1) of the table shows the results of ordinary least squares (OLS) regressions in which we relate job motivation to a treatment dummy that takes the value 1 if the employee was affected by the retrenchment in pension rights (i.e., born in 1950) and 0 otherwise. Since we have a sharp discontinuity in pension rights and observe only a small age difference between the treated and control groups, this is equivalent to a regression discontinuity approach (Van der Klaauw 2002). ${ }^{19}$ The result that unfair worker treatment evokes a reduction in job motivation is consistent with the evidence provided by the previous literature (e.g., Krueger and Mas 2004; Mas 2006, 2008). The main focus of this paper, however, is on the mechanism that generates the average treatment effect. So far, the literature has implicitly assumed that negative reciprocal inclinations drive this result. At the same time, there is evidence of substantial heterogeneity in negative reciprocal motives. If negative reciprocal inclinations drive the results, we would expect workers with stronger negative reciprocal inclinations to react more strongly to the unfair treatment and nonreciprocal workers to remain unaffected by the treatment. We are therefore not interested in an average treatment effect, but in an interaction effect between the treatment dummy and the indicator of negative reciprocity.

Column (2) of Table 2 shows OLS regressions in which we relate job motivation to a treatment dummy, the measures of negative and positive reciprocity, two interaction terms between the measures of reciprocity and the treatment dummy, age (relative to the discontinuity, in days divided by 365), and two interaction terms between the measures of reciprocity and age. Column (1) of Table 3 shows that the treatment effect is indeed heterogeneous with respect to reciprocal behavior. The coefficient of the interaction between negative reciprocity and the treatment dummy is negative and statistically significantly different from zero, indicating that the negative treatment effect is significantly stronger for the negatively reciprocal workers. ${ }^{20}$ More precisely, an increase of

\footnotetext{
${ }^{19}$ Table A2 in Web Appendix A shows additional robustness analyses on the relationship between job motivation and the treatment.

${ }^{20}$ In control analyses, we estimated the impact of unfair treatment on job motivation for the different quartiles of the distribution of negative reciprocity. The comparison of the treatment dummy across the different quartiles confirms that the treatment effect is heterogenous with respect to reciprocal behavior: The difference in job motivation is highest and statistically significant among treated
} 
Table 2 Negative Reciprocity, Treatment, and Job Motivation: OLS Estimates

\begin{tabular}{|c|c|c|c|c|c|c|}
\hline & (1) & (2) & (3) & (4) & (5) & (6) \\
\hline Negative reciprocity $\times$ Treatment & & $\begin{array}{c}-0.173^{* *} \\
(0.080)\end{array}$ & $\begin{array}{c}-0.173^{* *} \\
(0.080)\end{array}$ & $\begin{array}{c}-0.174^{* *} \\
(0.080)\end{array}$ & $\begin{array}{c}-0.228^{* *} \\
(0.106)\end{array}$ & $\begin{array}{c}-0.192^{* *} \\
(0.085)\end{array}$ \\
\hline Positive reciprocity $\times$ Treatment & & $\begin{array}{r}-0.038 \\
(0.126)\end{array}$ & $\begin{array}{r}-0.038 \\
(0.126)\end{array}$ & $\begin{array}{r}-0.030 \\
(0.127)\end{array}$ & $\begin{array}{l}0.053 \\
(0.145)\end{array}$ & $\begin{array}{r}-0.040 \\
(0.134)\end{array}$ \\
\hline Negative reciprocity & & $\begin{array}{c}-0.107^{* *} \\
(0.046)\end{array}$ & $\begin{array}{c}-0.107^{* *} \\
(0.046)\end{array}$ & $\begin{array}{c}-0.103^{* *} \\
(0.052)\end{array}$ & $\begin{array}{r}-0.075 \\
(0.063)\end{array}$ & $\begin{array}{r}-0.087^{*} \\
(0.050)\end{array}$ \\
\hline Positive reciprocity & & $\begin{array}{c}0.016 \\
(0.073)\end{array}$ & $\begin{array}{c}0.016 \\
(0.073)\end{array}$ & $\begin{array}{r}-0.018 \\
(0.083)\end{array}$ & $\begin{array}{r}-0.060 \\
(0.091)\end{array}$ & $\begin{array}{c}0.019 \\
(0.078)\end{array}$ \\
\hline Treatment & $\begin{array}{l}-0.163^{* * *} \\
(0.063)\end{array}$ & $\begin{array}{c}0.465 \\
(0.529)\end{array}$ & $\begin{array}{c}0.467 \\
(0.530)\end{array}$ & $\begin{array}{c}0.435 \\
(0.532)\end{array}$ & $\begin{array}{c}0.278 \\
(0.587)\end{array}$ & $\begin{array}{l}0.541 \\
(0.564)\end{array}$ \\
\hline Age & $\begin{array}{l}0.150^{* * *} \\
(0.054)\end{array}$ & $\begin{array}{c}-0.002 \\
(0.454)\end{array}$ & $\begin{array}{c}-0.007 \\
(0.461)\end{array}$ & $\begin{array}{c}0.015 \\
(0.456)\end{array}$ & $\begin{array}{c}0.364 \\
(0.718)\end{array}$ & $\begin{array}{c}-0.106 \\
(0.488)\end{array}$ \\
\hline Age $\times$ Treatment & & & $\begin{array}{c}0.007 \\
(0.109)\end{array}$ & & & \\
\hline Age $\times$ Negative reciprocity & & $\begin{array}{c}0.060 \\
(0.070)\end{array}$ & $\begin{array}{c}0.060 \\
(0.070)\end{array}$ & $\begin{array}{c}0.072 \\
(0.100)\end{array}$ & $\begin{array}{c}0.052 \\
(0.104)\end{array}$ & $\begin{array}{c}0.061 \\
(0.074)\end{array}$ \\
\hline Age $\times$ Positive reciprocity & & $\begin{array}{c}-0.001 \\
(0.107)\end{array}$ & $\begin{array}{r}-0.001 \\
(0.108)\end{array}$ & $\begin{array}{r}-0.095 \\
(0.153)\end{array}$ & $\begin{array}{c}-0.068 \\
(0.155)\end{array}$ & $\begin{array}{c}0.017 \\
(0.115)\end{array}$ \\
\hline$A g e^{2}$ & & & & $\begin{array}{r}-0.303 \\
(0.413)\end{array}$ & $\begin{array}{c}-0.324 \\
(0.414)\end{array}$ & \\
\hline Age $^{2} \times$ Negative reciprocity & & & & $\begin{array}{c}0.001 \\
(0.006)\end{array}$ & $\begin{array}{r}-0.022 \\
(0.031)\end{array}$ & \\
\hline Age $^{2} \times$ Positive reciprocity & & & & $\begin{array}{c}-0.007 \\
(0.008)\end{array}$ & $\begin{array}{c}0.027 \\
(0.031)\end{array}$ & \\
\hline$A g e^{3}$ & & & & & $\begin{array}{c}-0.378 \\
(0.623)\end{array}$ & \\
\hline $\mathrm{Age}^{3} \times$ Negative reciprocity & & & & & $\begin{array}{r}-0.001 \\
(0.001)\end{array}$ & \\
\hline Age $^{3} \times$ Positive reciprocity & & & & & $\begin{array}{c}0.001 \\
(0.001)\end{array}$ & \\
\hline Number of years contributed to the pension fund & & & & & & $\begin{array}{r}-0.004 \\
(0.003)\end{array}$ \\
\hline Log yearly wage & & & & & & $\begin{array}{l}0.287^{* * *} \\
(0.089)\end{array}$ \\
\hline Organization size & & & & & & $\begin{array}{c}0.005 \\
(0.015)\end{array}$ \\
\hline Married & & & & & & $\begin{array}{l}0.149 * * \\
(0.061)\end{array}$ \\
\hline Constant & $\begin{array}{l}3.418^{* * *} \\
(0.036)\end{array}$ & $\begin{array}{l}3.652^{* * *} \\
(0.307)\end{array}$ & $\begin{array}{l}3.650^{* * *} \\
(0.310)\end{array}$ & $\begin{array}{l}3.771^{* * *} \\
(0.347)\end{array}$ & $\begin{array}{l}3.853^{* * *} \\
(0.370)\end{array}$ & $\begin{array}{c}0.329 \\
(1.031)\end{array}$ \\
\hline Observations & 5,287 & 5,182 & 5,182 & 5,182 & 5,182 & 4,524 \\
\hline
\end{tabular}

Notes. The measures of negative and positive reciprocity used as explanatory variables in the regressions are constructed by taking the average of the three underlying items. Additional control variables in the estimations in column (6) are educational levels and sector fixed effects. Standard errors are in parentheses. ${ }^{*} p<0.10 ;{ }^{* *} p<0.05 ;{ }^{* * *} p<0.01$.

one standard deviation on the negative reciprocity scale $(0.79)$ reduces job motivation of treated workers by 0.136 . Table 3 also shows that negative reciprocity generally reduces the job motivation of all workers significantly, whereas positive reciprocity has

workers in the upper quartile of the negative reciprocity distribution and lowest among the least negatively reciprocal treated workers. no significant impact. We find, as can be expected, that the interaction between positive reciprocity and the treatment variable has no effect on the level of job motivation.

Columns (3)-(6) of Table 2 show that our key result, that the reduction in job motivation of workers whose pension rights are curbed depends on the level of their negatively reciprocal inclinations, is robust to the inclusion of an interaction between age and treatment, 
Table 3 Treatment Effect on Job Motivation: Results for Different Birth Date Bandwidths

\begin{tabular}{|c|c|c|}
\hline & $\begin{array}{c}(1) \\
\text { I } 1950 \text { vs. } \\
\text { IV } 1949\end{array}$ & $\begin{array}{c}\text { (2) } \\
\text { II-IV } 1950 \text { vs. } \\
\text { IV } 1949\end{array}$ \\
\hline Negative reciprocity $\times$ Treatment & $\begin{array}{c}-0.354^{* *} \\
(0.160)\end{array}$ & $\begin{array}{c}-0.123 \\
(0.126)\end{array}$ \\
\hline Positive reciprocity $\times$ Treatment & $\begin{array}{c}0.128 \\
(0.262)\end{array}$ & $\begin{array}{r}-0.057 \\
(0.196)\end{array}$ \\
\hline Negative reciprocity & $\begin{array}{c}-0.011 \\
(0.092)\end{array}$ & $\begin{array}{c}-0.095 \\
(0.062)\end{array}$ \\
\hline Positive reciprocity & $\begin{array}{c}-0.069 \\
(0.153)\end{array}$ & $\begin{array}{c}0.050 \\
(0.101)\end{array}$ \\
\hline Treatment & $\begin{array}{c}0.565 \\
(1.093)\end{array}$ & $\begin{array}{c}0.377 \\
(0.826)\end{array}$ \\
\hline Age & $\begin{array}{c}1.166 \\
(3.835)\end{array}$ & $\begin{array}{c}0.290 \\
(0.926)\end{array}$ \\
\hline Age $\times$ Negative reciprocity & $\begin{array}{c}0.644 \\
(0.562)\end{array}$ & $\begin{array}{c}-0.036 \\
(0.146)\end{array}$ \\
\hline Age $\times$ Positive reciprocity & $\begin{array}{c}-0.966 \\
(0.910)\end{array}$ & $\begin{array}{c}-0.004 \\
(0.218)\end{array}$ \\
\hline Constant & $\begin{array}{l}3.601^{* * *} \\
(0.641)\end{array}$ & $\begin{array}{l}3.494^{* * *} \\
(0.427)\end{array}$ \\
\hline Observations & 1,280 & 2,526 \\
\hline
\end{tabular}

Notes. OLS estimates are shown. In column (1), workers born in the first quarter of 1950 are compared to workers in the control group who were born in the fourth quarter of 1949, which corresponds to the optimal bandwidth that we derived by implementing the procedure of Imbens and Kalyanaraman (2012). Column (2) compares workers born in the second, third, or fourth quarter of 1950 with those born in the fourth quarter of 1949. Standard errors are in parentheses.

${ }^{* *} p<0.05 ;{ }^{* * *} p<0.01$.

and higher-order age polynomials. ${ }^{21}$ Column (6) further shows that our key result remains when control variables are included (including annual wage income (in logs), the number of years in which workers have built up their pension, marital status, educational attainment, and employment subsector). ${ }^{22}$ An increase of one standard deviation in the negative reciprocity scale now reduces job motivation of treated workers by 0.152 , which is equivalent to having an annual wage that is $0.5 \%$ lower.

\footnotetext{
${ }^{21}$ We also estimated models in which we additionally interacted age with the two interaction terms between the measures of reciprocity and the treatment dummy. Although multicollinearity issues arise for the positive reciprocity indicator, we find that the coefficient of the interaction term between negative reciprocity and the treatment dummy is robust to the inclusion of these interactions.

${ }^{22}$ The policy has an impact only on the workers who choose the early retirement scheme. Because most workers retired at the age of 62 or younger before 2006, they are indeed curtailed in their early retirement plans. However, we included the expected retirement age and its interaction with negative reciprocity in an additional analysis to control for early retirement preferences. We found that the coefficient of the interaction between treatment and negative reciprocity is robust to the inclusion of these variables.
}

Table A3 in Web Appendix A shows that the results presented in Table 2 are also robust to the estimation technique: Ordered probit estimates that deal with the discreteness of job motivation lead to exactly the same conclusion. ${ }^{23}$ Furthermore, Table A4 in Web Appendix A shows that the interaction effect between the three separate individual negative reciprocity items and the treatment dummy on job motivation is negative for all three items and statistical significant for the first two items. ${ }^{24}$

\subsection{Perceived Unfairness of Policy Change}

Until now, we have implicitly presupposed that the perceived unfairness brought about by the retrenchment in pension rights is the same among all treated workers. However, there may be differences in perceived unfairness. We would expect that those who feel treated most unfairly among the negatively reciprocal react more strongly to the policy change. Unfortunately, we do not have a direct measure of perceived unfairness, but it is plausible to assume that workers who were born only shortly after the treatment threshold perceive the policy change as more unfair; they compare their pension rights to the rights of those born just a few days earlier but who still enjoy the older more generous plan. Accordingly, we expect that strongly negatively reciprocal workers in this specific group will be more demotivated than workers born later in 1950 .

We test this conjecture by comparing the job motivation of workers born in different quarters in $1950 .^{25}$ The treatment group in column (1) of Table 3 consists

\footnotetext{
${ }^{23}$ The results are also robust to the use of a semi-nonparametric estimator for a series of generalized models that nest the ordered probit model and thereby relax the distributional assumptions in that model (see Stewart 2004).

${ }^{24}$ In additional robustness checks, we investigate whether our results are sensitive to the construction of our reciprocity measures. We estimate ordered probit models, including alternative measures of negative and positive reciprocity constructed based on principal component analysis on the six underlying items, and find that the interaction effect between negative reciprocity and the treatment group remains highly significant.

${ }^{25}$ We also checked whether the effect of the interaction between the treatment dummy and negative reciprocity can be attributed to quarter-of-birth effects. We reestimated our preferred specification for a restricted sample of employees that includes only those born in the first quarter of 1949 and those born in the first quarter of 1950. Moreover, we estimated a specification in which we replaced the birth date variable by birth quarter dummies. In both cases, we find that the interaction effect between reciprocity and the treatment dummy remains strongly significant. These results indicate that quarter-of-birth effects are very unlikely to drive the results. This conclusion is supported by Figures A6 and A7 in Web Appendix A, which plot birth quarter averages of job motivation and local polynomial estimates of job motivation on birth date for the treatment and control groups together (with 95\% confidence intervals) for employees who score above and below the median of the negative reciprocity scale, respectively. If seasonality caused the
} 
of workers who were born in the first quarter of 1950, whereas the treatment group in column (2) consists of workers born in the second, third, or fourth quarter of 1950. In both columns, the control group consists of those born in the fourth quarter of 1949. The bandwidth selection in column (1) corresponds to the optimal bandwidth that we derived by implementing the procedure of Imbens and Kalyanaraman (2012). This procedure enables the calculation of the optimal bandwidth for regression discontinuity designs through the minimization of an expected squared error loss criterion. ${ }^{26}$

Table 3 shows that our results are robust to applying the optimal bandwidth derived by the procedure of Imbens and Kalyanaraman (2012) and confirms our expectation that negatively reciprocal workers born on or just after January 1, 1950, are more demotivated than workers born later that year. The coefficient of the interaction term between negative reciprocity and the treatment variable remains substantial and significant in column (1), whereas the negative effect for workers born in later quarters of 1950 is smaller (column (2)). However, a regression on the whole sample in which we interact the model with a dummy variable measuring whether employees are born in the first quarter of 1950 indicates that the difference between the coefficients in both regressions is not statistically significant (the coefficient of the triple interaction between birth quarter, negative reciprocity, and treatment is -0.51 , with a $p$-value of 0.582$).{ }^{27}$

drop in job motivation, instead of the treatment, one would expect the slope of the relationship between job motivation and the birth date to be similar for strongly negative reciprocal employees and for those who have less strongly negatively reciprocal inclinations. In particular, one would expect the exact same pattern around the cutoff date. The figures, however, show that this is clearly not the case: whereas there is a strong discontinuity in job motivation at the cutoff date for employees with above-median negatively reciprocal inclinations, there is no evidence of a significant drop in job motivation for employees with below-median negatively reciprocal inclinations.

${ }^{26}$ The idea behind the procedure of Imbens and Kalyanaraman (2012) is that the optimal bandwidth should increase when the variance in outcomes increases at the cutoff, when the density of the forcing variable (age) is smaller, or when the shapes of the curves on both sides of the cutoff becomes increasingly symmetrical.

${ }^{27}$ It is conceivable that the degree to which workers feel affected by the pension reform depends on the perceived costs. These costs in turn depend on retirement expectations and retirement intentions. In particular, we hypothesize that treated workers who expect a relatively low pension after the reform, or who expect to work relatively longer, feel more strongly affected by the retrenchment of their pension rights than treated workers who expect to be affected less strongly in terms of drop in pension wealth. We examined this hypothesis by assessing (1) whether job motivation is lower for treated negatively reciprocal employees who expect to receive a pension benefit below the median in the treatment group than for negatively reciprocal employees who expect to receive a
It is also intuitive to assume that the extent to which colleagues in a worker's organization suffer from the reform affects the perceived fairness of the policy change. Since workers tend to compare the rewards of their efforts to those their colleagues receive, we conjecture that treated employees suffer more from the reform the higher the fraction of untreated employees working in their organization (see also Fliessbach et al. 2007, Clark and Senik 2010, Gächter et al. 2013). To construct a proxy for the degree of social comparison, we rely on administrative data to calculate for each public sector organization the fraction of untreated employees born in 1949 and the total number of workers in the organization. ${ }^{28} \mathrm{We}$ then run separate regressions for workers in organizations whose share of untreated workers is below the median and those in organizations whose share of untreated workers is at or above the median. Table 4 shows that the coefficient of the interaction term between the treatment dummy and the negative reciprocity measure is almost four times as large for the group of workers who have a higher share of colleagues who are unaffected by the reform. A regression analysis in which we interact the model with a dummy variable that indicates whether employees work in organizations whose share of untreated workers is above the median shows that this difference is significant at the $10 \%$ level (the coefficient of the triple interaction between the share of untreated colleagues, negative reciprocity, and the treatment is -0.154 with a $p$-value of 0.065 ). This finding corroborates the hypothesis that the perception of being treated unfairly causes negatively reciprocal employees to retaliate against their employer by providing less effort. ${ }^{29}$

\subsection{The Employer-Employee Relation}

Employer accountability for unfair treatment is a precondition for the directed retaliation of workers. We

pension benefit above the median in the treatment group, and (2) whether job motivation is lower for treated negatively reciprocal employees who expect that they have to postpone their retirement due to the reform for longer than the median employee in the treatment group. The results indeed show that job motivation is lowest among treated negatively reciprocal employees who expect low pensions and who expect they have to work longer due to the reform.

${ }^{28}$ Unfortunately, we do not have administrative data on the age distribution of the total workforce in organizations. We can therefore only look at the fraction of untreated employees who were born in 1949 .

${ }^{29}$ Using the same data as we use, de Grip et al. (2012) recently showed that the unexpected drop in pension rights also increases the likelihood of becoming depressed. We checked whether the lower job motivation of treated workers could be a byproduct of mental health deterioration and find that adding the depression rate as a control variable to our analyses does not change our key result. 
Table 4

Treatment Effect on Job Motivation: Social Comparisons

\begin{tabular}{lcc}
\hline & $(1)$ & $(2)$ \\
& Percentage & Percentage \\
untreated & untreated \\
colleagues & colleagues \\
above median & below median \\
\hline Negative reciprocity $\times$ Treatment & $-0.269^{* *}$ & -0.074 \\
& $(0.115)$ & $(0.116)$ \\
Positive reciprocity $\times$ Treatment & 0.090 & -0.169 \\
& $(0.185)$ & $(0.179)$ \\
Negative reciprocity & -0.089 & $-0.118^{*}$ \\
& $(0.065)$ & $(0.069)$ \\
Positive reciprocity & -0.031 & 0.038 \\
Treatment & $(0.104)$ & $(0.107)$ \\
Age & 0.220 & 0.750 \\
& $(0.784)$ & $(0.748)$ \\
Age $\times$ Negative reciprocity & 0.603 & -0.572 \\
& $(0.668)$ & $(0.638)$ \\
Age $\times$ Positive reciprocity & 0.075 & 0.012 \\
Constant & $(0.100)$ & $(0.101)$ \\
& -0.163 & 0.162 \\
Observations & $(0.157)$ & $(0.152)$ \\
\hline Notes. All & $3.777 * * *$ & $3.594^{* * *}$ \\
& $(0.436)$ & $(0.450)$ \\
& 2,542 & 2,472 \\
\hline
\end{tabular}

Notes. All columns show results that are based on OLS estimates. We use administrative data on the total number of workers in the organization in which each employee is working to construct proxies for the incidence of social comparisons in the organization. We determine whether treated workers who were born in 1950 are working in an organization in which the group of untreated workers who were born in 1949 is comparatively large (percentage untreated above or under median). Standard errors are in parentheses.

${ }^{*} p<0.10 ;{ }^{* *} p<0.05 ;{ }^{* * *} p<0.01$.

therefore expect negatively reciprocal workers who hold their employer responsible for unfair treatment to purposefully retaliate against their employer. It is very likely that public sector employees hold their employer responsible for the retrenchment of pension rights, because the government, which is regarded as the public sector's corporate management, initiated the pension reform by abolishing the favorable tax treatment. This accountability in management is an important reason for focusing on public sector employees. Nevertheless, it seems straightforward to conjecture that the extent to which employees hold their employer responsible may differ across the different Dutch public subsectors. ${ }^{30}$ Since the government initiated the policy reform, it is plausible to con-

\footnotetext{
${ }^{30}$ The 15 subsectors are as follows: the national government departments; defense (only civilian personnel); provinces; municipalities; the judiciary; primary and secondary education; intermediate vocational education; higher vocational education; universities; the research and scientific policy sector; teaching hospitals; district water boards; water, energy, and public utilities; voluntary members (including $\mathrm{ABP}$ and public transport); and a remaining category.
}

jecture that civil servants who work for the government most strongly assign the blame for the unfair treatment directly to their own employer. Consequently, we expect that the treatment effect is greater among negatively reciprocal workers in the government departments. ${ }^{31}$

Estimating the impact of the reform separately for workers employed in the national government, other governmental sectors, and those in the education sector and privatized sector (e.g., water, energy and public utilities; public transport companies), we find that only the coefficient of the interaction between the treatment term and our indicator for negative reciprocity is statistically significant, and that it is also much greater for employees in the government departments than in the other sectors, as a comparison of OLS estimates in columns (1)-(4) of Table 5 reveals. A regression on the whole sample in which we interact with a dummy variable measuring whether employees work in the national government indicates that treated employees in the national government with negatively reciprocal inclinations have a significantly lower job motivation than employees in the other sectors (coefficient of the triple interaction between sector, negative reciprocity, and treatment is -0.214 with a $p$-value of 0.039$)$. This confirms the conjecture that employees who can directly associate the unfair treatment to their own employer show stronger negative reciprocal behavior through a reduction in job motivation.

4.3.1. Workers with Career Breaks. The results of further robustness checks shown in Table A5 in Web Appendix A buttress our findings. This analysis includes workers with career breaks after April 1997. Although it is conceivable that these workers' career interruptions were caused by unobserved individual characteristics that may also be related to reciprocal behavior, the inclusion of these workers introduces an additional treatment group. Remember that the legislative change also curtailed the pensions of those born in 1949 and before if they did not work continuously in the public sector since April 1997. Columns (1) (without control variables) and (3) (with control variables) present estimation results only for workers born in 1949. The treatment dummy equals one for workers born in 1949 but not entitled to the old pension rights since they did not work continuously since April 1997, whereas the dummy is zero for all workers in 1949 who remain entitled. The estimation results show a significant and negative coefficient of the interaction between the treatment variable and negative reciprocity when control variables are added.

\footnotetext{
${ }^{31}$ We checked whether workers in the different subsectors differ with respect to negative reciprocal inclinations, but found that such differences are very small and statistically not significant.
} 
Table 5

Treatment Effect on Job Motivation: Heterogenous Sector Effects

\begin{tabular}{|c|c|c|c|c|}
\hline & $\begin{array}{c}(1) \\
\text { National } \\
\text { government }\end{array}$ & $\begin{array}{l}(2) \\
\text { Other governmental } \\
\text { sectors }\end{array}$ & $\begin{array}{c}\text { (3) } \\
\text { Education } \\
\text { sectors }\end{array}$ & $\begin{array}{c}(4) \\
\text { Privatized } \\
\text { sectors }\end{array}$ \\
\hline Negative reciprocity $\times$ Treatment & $\begin{array}{c}-0.429 * * \\
(0.183)\end{array}$ & $\begin{array}{c}-0.158 \\
(0.147)\end{array}$ & $\begin{array}{c}-0.044 \\
(0.129)\end{array}$ & $\begin{array}{c}-0.075 \\
(0.266)\end{array}$ \\
\hline Positive reciprocity $\times$ Treatment & $\begin{array}{c}0.445 \\
(0.285)\end{array}$ & $\begin{array}{c}-0.114 \\
(0.232)\end{array}$ & $\begin{array}{c}-0.217 \\
(0.202)\end{array}$ & $\begin{array}{c}-0.286 \\
(0.449)\end{array}$ \\
\hline Negative reciprocity & $\begin{array}{c}0.076 \\
(0.108)\end{array}$ & $\begin{array}{c}-0.175^{* *} \\
(0.089)\end{array}$ & $\begin{array}{r}-0.144^{*} \\
(0.074)\end{array}$ & $\begin{array}{c}-0.224 \\
(0.150)\end{array}$ \\
\hline Positive reciprocity & $\begin{array}{c}-0.148 \\
(0.167)\end{array}$ & $\begin{array}{c}0.005 \\
(0.135)\end{array}$ & $\begin{array}{c}0.113 \\
(0.117)\end{array}$ & $\begin{array}{c}0.199 \\
(0.256)\end{array}$ \\
\hline Treatment & $\begin{array}{c}-0.930 \\
(1.182)\end{array}$ & $\begin{array}{c}0.817 \\
(0.951)\end{array}$ & $\begin{array}{c}0.871 \\
(0.863)\end{array}$ & $\begin{array}{c}1.383 \\
(1.834)\end{array}$ \\
\hline Age & $\begin{array}{l}1.840^{*} \\
(1.020)\end{array}$ & $\begin{array}{c}-0.202 \\
(0.801)\end{array}$ & $\begin{array}{c}-0.725 \\
(0.763)\end{array}$ & $\begin{array}{c}-0.668 \\
(1.469)\end{array}$ \\
\hline Negative reciprocity $\times$ Age & $\begin{array}{c}0.136 \\
(0.161)\end{array}$ & $\begin{array}{c}0.093 \\
(0.127)\end{array}$ & $\begin{array}{c}-0.087 \\
(0.113)\end{array}$ & $\begin{array}{c}0.177 \\
(0.225)\end{array}$ \\
\hline Positive reciprocity $\times$ Age & $\begin{array}{r}-0.462^{*} \\
(0.245)\end{array}$ & $\begin{array}{c}0.009 \\
(0.193)\end{array}$ & $\begin{array}{c}0.253 \\
(0.176)\end{array}$ & $\begin{array}{c}0.030 \\
(0.363)\end{array}$ \\
\hline Constant & $\begin{array}{l}3.973^{* * * *} \\
(0.682)\end{array}$ & $\begin{array}{l}3.911^{* * *} \\
(0.551)\end{array}$ & $\begin{array}{l}3.248^{* * *} \\
(0.502)\end{array}$ & $\begin{array}{l}3.144^{* * *} \\
(1.055)\end{array}$ \\
\hline Observations & 1,014 & 1,462 & 2,038 & 500 \\
\hline
\end{tabular}

Notes. OLS estimates are given, with standard errors in parentheses. The three subsectors that form the national government are the national government, provinces, and voluntary members (which includes ABP). The other governmental sectors are municipalities, the judiciary, defense (only civilian personnel), district water boards, and teaching hospitals. The education sectors include primary and secondary education, intermediate vocational education, higher vocational education, universities, and the research and scientific policy sector. The privatized sectors include water, energy and public utilities, and the remaining category.

${ }^{*} p<0.10 ;{ }^{* *} p<0.05 ;{ }^{* * *} p<0.01$.

Therefore, for this specific treatment group, we also find that primarily negatively reciprocal workers with curtailed pension rights are strongly demotivated.

Columns (2) (without control variables) and (4) (with control variables) of Table A5 contain estimation results for the full 1949 and 1950 sample and include two treatment dummy variables. The first treatment dummy equals one for workers born in 1949 and not entitled to the old pension rights, and zero otherwise. The second treatment dummy equals one if the workers were born in 1950, and zero if they were born in 1949. The estimation results show that both interactions between the treatment dummy variables and negative reciprocity are negative and significantly different from zero in the specification that includes the control variables. Moreover, the sizes of coefficients of both treatment dummy variables are remarkably similar.

\section{Conclusion}

This paper shows that reciprocity is an important determinant of job motivation. Using a natural experiment, we find that a decrease in pension rights is associated with lower job motivation among negatively reciprocal employees. Moreover, negatively reciprocal workers born in the first three months of 1950 are more demotivated than those born later in the year, plausibly because the former perceive the differential tax treatment as more unfair because their age hardly differs from that of those not affected by the reform. Moreover, we observe that the coefficient of the interaction term between the treatment dummy and negative reciprocity is substantially larger for workers who have a higher share of colleagues who are not covered by the reform. We also find that negatively reciprocal workers employed by the national government, i.e., those who can directly associate their unfair treatment to their own employer, have lower job motivation than those employed in other public subsectors. Furthermore, our results are robust to the use of alternative estimation methods.

Our findings indicate that pension reforms intended to increase labor force participation can be distorted by reducing job motivation of negatively reciprocal workers who feel unfairly treated. Therefore, it is crucial to think of reform designs that provide less scope for being perceived as unfair by particular groups. In the specific example of tax legislation affecting pension rights, an alternative design that entails smaller discontinuous differences 
in pension rights would arguably cause less disruption in terms of negatively reciprocal responses.

Our findings complement the literature in important ways. First, we exploit exogenous variation in unfair worker treatment to shed light on the nature of the relationship between unfair worker treatment and undesired worker response. In accordance with an ultimatum game, the drop in motivation can be interpreted as the sanctioning of unkind or hostile actions (e.g., Güth et al. 1982, Camerer and Thaler 1995). Our evidence shows that negatively reciprocal individuals not only sanction actions they perceive as unkind or hostile in laboratory settings, but behave similarly when they feel treated unfairly by their employers. Second, we use a direct measure of reciprocal inclination to test whether the response of workers is brought about by negative reciprocal motives, and we provide evidence for a causal link between negatively reciprocal inclinations and reductions in job motivation. Third, we show that heterogeneity in negatively reciprocal inclinations leads to heterogeneity in the job motivation of workers who feel treated unfairly. These findings are fundamental, since they indicate that reciprocal behavior is strongly driven by social motives.

\section{Supplemental Material}

Supplemental material to this paper is available at http://dx .doi.org/10.1287/mnsc.2015.2157.

\section{Acknowledgments}

The authors thank Lex Borghans, Eric Bonsang, Denis de Crommbrugghe, Robert Dur, Armin Falk, Michel Lubrano, Olivier Marie, Arjan Non, Arno Riedl, Jan Sauermann, Uwe Sunde, the associate editor, three anonymous referees, and participants at various seminars, workshops, and conferences for their helpful comments. Financial support from the Network for Studies on Pensions, Aging, and Retirement (Netspar); Instituut GAK; the Ministry of Social Affairs and Employment; and the Netherlands Organisation for Scientific Research (NWO) is gratefully acknowledged.

\section{References}

Akerlof GA (1982) Labor contracts as partial gift exchange. Quart. J. Econom. 97:543-569.

Bateman TS, Organ DW (1983) Job satisfaction and the good soldier: The relationship between affect and employee "citizenship." Acad. Management J. 26:687-595.

Batt R (2002) Managing customer services: Human resource practices, quit rates, and sales growth. Acad. Management J. 45:587-597.

Bellemare C, Kröger S (2007) On representative social capital. Eur. Econom. Rev. 51:183-202.

Bellemare C, Shearer B (2009) Gift giving and worker productivity: Evidence from a firm-level experiment. Games Econom. Behav. 67:233-244.

Berg J, Dickhaut J, McCabe K (1995) Trust, reciprocity and social history. Games Econom. Behav. 10:122-142.

Berger J, Pope D (2011) Can losing lead to winning? Management Sci. 5:817-827.
Bowles S (2008) Policies designed for self-interested citizens may undermine "the moral sentiments": Evidence from economic experiments. Science 320:1605-1609.

Bowles S, Gintis H, Osborne M (2001) The determinants of earnings: Skills, preferences, and schooling. J. Econom. Literature 39:1137-1176.

Brown M, Falk A, Fehr E (2004) Relational contracts and the nature of market interactions. Econometrica 72:747-780.

Camerer CF, Hogarth R (1999) The effects of financial incentives in experiments: A review and capital-labor-production framework. J. Risk Uncertainty 19:7-42.

Camerer CF, Thaler R (1995) Ultimatums, dictators and manners. J. Econom. Perspect. 9:209-219.

Clark AE, Senik C (2010) Who compares to whom? The autonomy of income comparisons in Europe. Econom. J. 120:573-594.

Cohn A, Fehr E, Goette L (2015) Fair wages and effort provision: Combining evidence from a choice experiment and a field experiment. Management Sci. 61:1777-1794.

Cohn A, Fehr E, Herrmann B, Schneider F (2014) Social comparison and effort provision: Evidence from a field experiment. J. Eur. Econom. Assoc. 12:877-898.

Cooper-Hakim A, Viswesvaran C (2005) The construct of work commitment: Testing an integrative framework. Psych. Bull. 131:241-259.

de Grip A, Lindeboom M, Montizaan R (2012) Shattered dreams: The effects of changing the pension system late in the game. Econom. J. 122:1-25.

Dohmen T, Falk A, Huffman D, Sunde U (2009) Homo reciprocans: Survey evidence on behavioral outcomes. Econom. J. 119: 592-612.

Dohmen T, Falk A, Huffman D, Sunde U, Schupp J, Wagner W (2011) Individual risk attitudes: Measurement, determinants and behavioral consequences. J. Eur. Econom. Assoc. 9:522-550.

Dunifon R, Duncan G (1997) Long-run effects of motivation on labor-market success. Social Psych. Quart. 61:33-48.

Falk A (2007) Gift exchange in the field. Econometrica 7:1501-1511.

Falk A, Zehnder C (2013) A city-wide experiment on trust discrimination. J. Public Econom. 100:15-27.

Fehr E, Gächter S (2000) Fairness and retaliation. J. Econom. Perspect. 14:159-181.

Fehr E, Goette L, Zehnder C (2009) A behavioral account of the labor market: The role of fairness concerns. Annual Rev. Econom. 1:355-384.

Fehr E, Kirchsteiger G, Riedl A (1993) Does fairness prevent market clearing? An experimental investigation. Quart. J. Econom. 108: 437-460.

Fehr E, Kirchsteiger G, Riedl A (1998) Gift exchange and reciprocity in competitive experimental markets. Eur. Econom. Rev. 42:1-34.

Fehr E, Fischbacher U, von Rosenbladt B, Schupp J, Wagner GG (2002) A nation-wide laboratory: Examining trust and trustworthiness by integrating behavioral experiments into representative surveys. J. Appl. Soc. Sci. Stud. 122:519-542.

Fliessbach K, Weber B, Trautner P, Dohmen T, Sunde U, Elger C, Falk A (2007) Social comparison affects reward-related brain activity in the human ventral striatum. Science 318:1305-1308.

Gächter S, Nosenzo D, Sefton M (2013) Peer effects in pro-social behavior: Social norms or social preferences? J. Eur. Econom. Assoc. 11:548-573.

Gardner TM, Wright PM, Moynihan LM (2011) The impact of motivation, empowerment, and skill enhancing practices on aggregate voluntary turnover: The mediating effect of collective affective commitment. Personnel Psych. 64:315-350.

Gneezy U, List J (2006) Putting behavioral economics to work: Testing for gift exchange in labor markets using field experiments. Econometrica 74:1365-1384.

Greenberg J (1990) Employee theft as a reaction to underpayment inequity: The hidden cost of pay cuts. J. Appl. Psych. 7:561-568.

Güth W, Schmittberger R, Schwarze B (1982) An experimental analysis of ultimatum bargaining. J. Econom. Behav. Organ. 3: 367-388.

Harrison DA, Newman DA, Roth PL (2006) How important are job attitudes? Meta-analytic comparisons of integrative behavioral outcomes and time sequences. Acad. Management J. 49:305-325. 
Harter JK, Hayes TL, Schmidt FL (2002) Business-unit-level relationship between employee satisfaction, employee engagement, and business outcomes: A meta-analysis. J. Appl. Psych. 2:268-279.

Huselid MA (1995) The impact of human resource management practices on turnover, productivity, and corporate financial performance. Acad. Management J. 38:635-672.

Ichniowski G, Shaw K, Prennushi G (1997) The effects of human resource management practices on productivity: A study of steel finishing lines. Amer. Econom. Rev. 87:291-313.

Imbens G, Kalyanaraman K (2012) Optimal bandwidth choice for the regression discontinuity estimator. Rev. Econom. Stud. 79:933-959.

Imbens G, Lemieux T (2008) Regression discontinuity designs: A guide to practice. J. Econometrics 142:615-635.

Jiang K, Lepak D (2012) How does human resource management influence organizational outcomes? A meta-analytic investigation of mediating mechanisms. Acad. Management J. 55: 1264-1294.

Judge T, Thoresen C, Bono J, Patton G (2001) The job satisfactionjob performance relationship: A qualitative and quantitative review. Psych. Bull. 127:376-407.

Kehoe RR, Wright PM (2013) The impact of high-performance human resource practices on employees' attitudes and behaviors. J. Management 39:366-391.

Krueger AB, Mas A (2004) Strikes, scabs and tread separations: Labor strife and the production of defective Bridgestone/ Firestone tires. J. Political Econom. 112:253-289.

Kube S, Maréchal M, Puppe C (2012) The currency of reciprocitygift-exchange in the workplace. Amer. Econom. Rev. 102: 1644-1662.

Kube S, Puppe C, Maréchal MA (2013) Do wage cuts damage work morale? Evidence from a natural field experiment. J. European Econom. Assoc. 4:853-870.

Lee DS, Lemieux T (2010) Regression discontinuity designs in economics. J. Econom. Literature 48:281-355.
Liao H, Toya K, Lepak DP, Hong Y (2009) Do they see eye to eye? Management and employee perspectives of high-performance work systems and influence processes on service quality. J. Appl. Psych. 94:371-391.

Mas A (2006) Pay, reference points, and policy performance. Quart. J. Econom. 121:783-821.

Mas A (2008) Labour unrest and the quality of production: Evidence from the construction equipment resale market. Rev. Econom. Stud. 75:229-258.

Montizaan R, de Grip A, Cörvers F (2009) The effects of pension rights and retirement age on training participation: Evidence from a natural experiment. Labour Econom. 17:240-247.

Montizaan R, Vendrik M (2014) Shocks in retirement expectations and subjective well-being: Evidence from a natural experiment. J. Econom. Behav. Organ. 97:1-26.

Patterson M, Warr P, West M (2004) Organizational climate and company productivity: The role of employee affect and employee level. J. Occupational Organ. Psych. 77:193-216.

Perugini M, Gallucci M, Presaghi F, Ercolani AP (2003) The personal norm of reciprocity. Eur. J. Personality 17:251-283.

Rabin M (1993) Incorporating fairness into game theory and economics. Amer. Econom. Rev. 83:1281-1302.

Riketta M (2002) Attitudinal organizational commitment and job performance: A meta-analysis. J. Organ. Behav. 23:257-266.

Riketta M (2008) The causal relation between job attitudes and performance: A meta-analysis of panel studies. J. Appl. Psych. 93:472-481.

Scott KD, Taylor GS (1985) An examination of conflicting findings on the relationship between job satisfaction and absenteeism: A meta-analysis. Acad. Management J. 28:599-612.

Stewart MB (2004) Semi-nonparametric estimation of extended ordered probit models. Stata J. 4:27-39.

Tucker C, Zhang J (2011) How does popularity information affect choices? A field experiment. Management Sci. 57:828-842.

Van der Klaauw W (2002) Estimating the effect of financial aid offers on college enrollment: A regression-discontinuity approach. Internat. Econom. Rev. 43:1249-1287. 